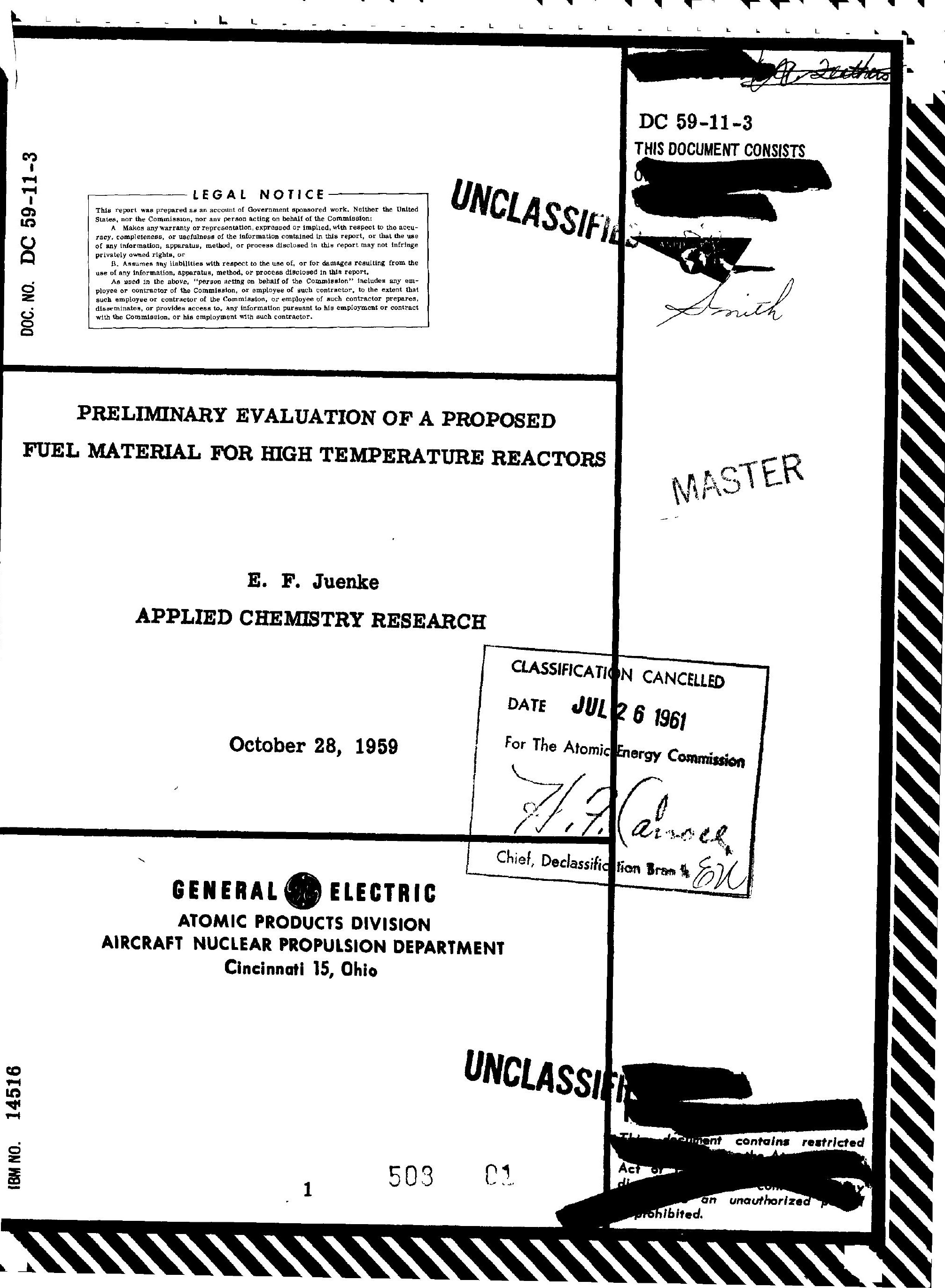




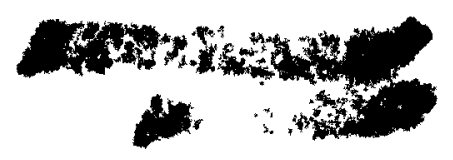

\section{PRELIMINARY REPORT}

This report is preliminary and informal in nature and was prepared for use at the Aircraft Nuclear Propulsion Department, General Electric Company in the course of work under AEC contract AT (11-1)-171, U.S. Air Force contract AF 33(038)-21102, or U.S. Air Force contract AF 33(600)-38062. Views, opinions, conclusions or proposals expressed in the report are those of the author(s) only. This report is subject to revision upon further evaluation or availability of additional data.
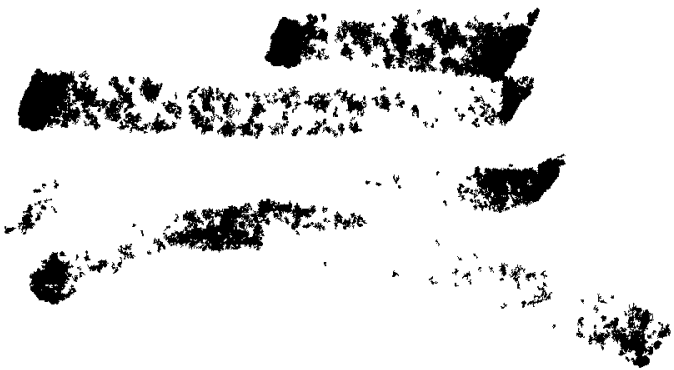


\section{DISCLAIMER}

This report was prepared as an account of work sponsored by an agency of the United States Government. Neither the United States Government nor any agency Thereof, nor any of their employees, makes any warranty, express or implied, or assumes any legal liability or responsibility for the accuracy, completeness, or usefulness of any information, apparatus, product, or process disclosed, or represents that its use would not infringe privately owned rights. Reference herein to any specific commercial product, process, or service by trade name, trademark, manufacturer, or otherwise does not necessarily constitute or imply its endorsement, recommendation, or favoring by the United States Government or any agency thereof. The views and opinions of authors expressed herein do not necessarily state or reflect those of the United States Government or any agency thereof. 


\section{DISCLAIMER}

Portions of this document may be illegible in electronic image products. Images are produced from the best available original document. 


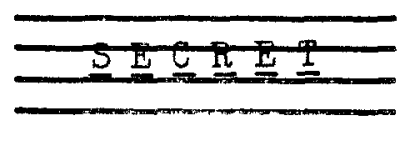

\section{DISTRIBUTION}

EA Aitken

HC Brassfield

VP Calkins

A Corbin

LA Feathers

EF Juenke

T Szekely

G Thornton

JB Trice

PP Turner

Library (3)

ITS Library (I)

\section{ABSTRACT}

Results are reported for some preliminary experiments to determine the stability - of solid solutions of $\mathrm{UO}_{2}$ and $\mathrm{ThO}_{2}$ in air at temperatures of $2500^{\circ} \mathrm{F}$ and above. The results are compared with those obtained by workers at Argonne National Laboratories during development work on the Borax IV experimental breeder reactor. It is concluded that further evaluation of the system at temperatures above $2500^{\circ} \mathrm{F}$ is required.

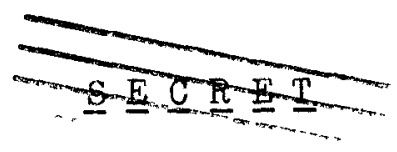




\title{
PRELIMINARY EVALUATION OF A PROPOSED FUEL MATERIAL FOR HIGH TEMPERATURE REACTORS
}

By

\author{
E。F。 Juenke
}

\section{INTRODUCTION}

Recently some interest has been exnressed in the system $\mathrm{ThO}_{2}-\mathrm{UO}_{2}$ both from the standpoint of a fuel additive for present ceramic fuel elements now under development and as an advanced fuel element for high temperature fast reactors.

Consequently, a program was undertaken to determine the high temperature stability of solid solutions of $\mathrm{UO}_{2}-\mathrm{ThO}_{2}$. This report summarizes the results obtained to date in a cursory evaluation conducted by the author and comnares these results with those obtained by J.H. Handwerk in studies conducted at Argonne National Laboratory. Further investigations are indicated.

\section{SUMMARY OF STUDIES CONDUCTED AT ANL ${ }^{(1)}$}

Preliminary development work on the preparation of $\mathrm{ThO}_{2}-\mathrm{UO}_{2}$ fuel elements for the Borax IV experimental breeder reactor has shown the following:

(I) $\mathrm{ThO}_{2}-\mathrm{UO}_{2}$ form a continuous solid solution of cubic fluorite structure.

(2) Additions of $\mathrm{ThO}_{2}$ stabilize $\mathrm{UO}_{2}$ in air up to $60 \mathrm{w} / \mathrm{UO}_{2}$. Above this percentage, X-ray analysis shows the presence of a second phase identified as $\mathrm{U}_{3} \mathrm{O}_{8}$.

(3) The $0 / 0$ ratio for the stable solid solution is $2.0-2.3$.

(4) Compositions containing un to $30 \mathrm{w} / \mathrm{O} \mathrm{UO}_{2}$, prepared by reacting $\mathrm{U}_{3} \mathrm{O}_{8}$ and $\mathrm{ThO}_{2}$ in air at $1750^{\circ} \mathrm{C}$, show no change in dimensions or weight after reheating, at $1400^{\circ} \mathrm{C}$ for 96 hours in air.

(5) Irradiation testing of a $97.5 \mathrm{w} / \mathrm{O} \mathrm{ThO}_{2}-2.5 \mathrm{w} / 0 \mathrm{UO}_{2}$ to a 0.94 atom burn-up of total metal atoms present shows no measurable dimensional changes but some microscopic cracking.

(6) Fueled pellets of $93.6 \mathrm{w} / \mathrm{O} \mathrm{ThO}_{2}-6.4 \mathrm{w} / \mathrm{O} \mathrm{UO}_{2}$, fabricated by sintering $\mathrm{U}_{3} \mathrm{O}_{8}$ and $\mathrm{ThO}_{2}$ at $1700^{\circ}-1750^{\circ} \mathrm{C}$ for $2 \mathrm{hrs}$ 。 in an over-all cycle of $16 \mathrm{hrs}$, attained $97 \%$ theoretical density.

(1) Handwerk, J.H. "Ceramic Fuel Elements in the $\mathrm{ThO}_{2}-\mathrm{UO}_{2}$ and $\mathrm{UO}_{2}-\mathrm{PuO}_{2}$ Systems", Paris Fuel Elements Conf。, TID-7546, Book 2, 526-47, March, 1958.

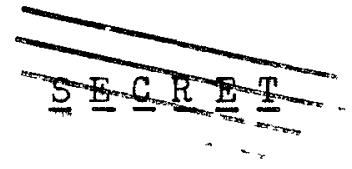




\section{SUMMARY OF PRELIMINARY EXPERIMENTS CONDUCTED AT ANPD}

Solid solutions of $\mathrm{UO}_{2}-\mathrm{ThO}_{2}$ were prepared in $10 \mathrm{w} / \mathrm{O}$ increments between $\left(90 \mathrm{w} / \mathrm{O} \mathrm{UO}_{2}-10 \mathrm{w} / 0 \mathrm{ThO}_{2}\right)$ and $\left(10 \mathrm{w} / 0 \mathrm{UO}_{2}-90 \mathrm{w} / 0 \mathrm{ThO}_{2}\right.$ ) by reaction of $\mathrm{UO}_{2}$ and $\mathrm{Th}\left(\mathrm{NO}_{3}\right)_{4} \cdot 4 \mathrm{H}_{2} \mathrm{O}$ for $4 \mathrm{hrs}$. in air at $1850^{\circ} \mathrm{C}$. $\mathrm{X}$-ray analysis indicated single phase $\mathrm{FCC}$ solid solution up to $90 \mathrm{w} / \mathrm{O} \mathrm{UO}_{2}$. At this percentage a second phase $\left(\mathrm{U}_{3} \mathrm{O}_{8}\right)$ was found to be present. The $\mathrm{O} / \mathrm{U}$ ratio, as determined by lattice parameter mea surements, was found to be very nearly 2.3 .

Pellets of the above compositions were cold pressed at 50,000 psi and subsequently sintered in air for $2 \mathrm{hrs}$. at $1800^{\circ} \mathrm{C}$. Densities varied from $85 \%$ to $90 \%$ of theoretical density for ideal $\left(\mathrm{UO}_{2.3}-\mathrm{ThO}_{2}\right)$ solid solutions. Fuel losses during this sintering process were found to range between $10 \mathrm{w} / \mathrm{o}$ and $20 \mathrm{w} / \mathrm{o}$, assuming that all weight loss was due to loss of $\mathrm{UO}_{2}$.

Pellets containing $80 \mathrm{w} / \mathrm{o}, 30 \mathrm{w} / \mathrm{o}$, and $10 \mathrm{w} / \mathrm{o} \mathrm{\textrm {UO } _ { 2 }}$ were sintered in an argon atmosphere for $4 \mathrm{hrs}$. at $1800^{\circ} \mathrm{C}$. The densities attained were $89 \%, 90 \%$, and $90 \%$ theoretical density respectively.

Additions of $1 \mathrm{w} / \mathrm{O} \mathrm{MgO}$ or $1 \mathrm{w} / \mathrm{CaO}$ did not appear to improve the sintering characteristics of the $\mathrm{UO}_{2}-\mathrm{ThO}_{2}$ solid solutions in inert atmospheres.

The pellets sintered in argon were subjected to a subsequert oxidation test of $24 \mathrm{hrs}$. at $2500^{\circ} \mathrm{F}$ in moving air. Additional weight losses of $2.3 \%, 0.6 \%$, and $0.4 \%$ were observed for the pellets containing $80 \mathrm{w} / \mathrm{o} \mathrm{vO} 2,30 \mathrm{w} / 0 \mathrm{UO}_{2}$, and 10 w/o $\mathrm{UO}_{2}$ respectively. These weight losses again refer to fuel loss based on the assumption that all weight loss is due to loss of $\mathrm{UO}_{2}$.

Argon-sintered pellets containing $1 \mathrm{w} / \mathrm{O} \mathrm{MgO}$ showed essentially the same weight losses as the argon-sintered $\left(\mathrm{UO}_{2.3}-\mathrm{ThO}_{2}\right)$ solid solutions when subjected to an identical oxidation treatment at $2500^{\circ} \mathrm{F}$.

THERMAL SHOCK RESISTANCE OF $\mathrm{ThO}_{2}$ AND UO $2-\mathrm{ThO}_{2}$ BODIES

Thoria has very poor resistance to thermal shock and stress because of its modulus of elasticity, relatively high thermal expansivity, and low thermal conductivity. Experiments have been conducted at Armour Research Foundation $(2)$ in which metallic fibers, such as niobium or molybdenum, were incorporated in $\mathrm{ThO}_{2}$ bodies. Such experiments have indicated that thermal shock resistance is improved and thermal conductivity increased in this manner. However, examination of these bodies after fabrication revealed numerous microcracks radiating from the metallic inclusions. Furthermore, upon heating in an oxidizing atmosphere for several hours at $1000^{\circ} \mathrm{C}$ the niobium or molybdenum fibers were found to be completely oxidized. Similar results were observed for $\mathrm{UO}_{2}-\mathrm{ThO}_{2}$ bodies containing up to $50 \mathrm{w} / \mathrm{O} \mathrm{UO}_{2}$.

(2) Baskin, Arenberg, and Handwerk; "Thoria Reinforced by Metal Fibers", Am. Ceramic Society Bulletin, Vol。38, No. 7, 1959.

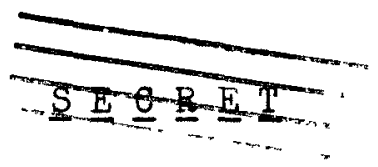




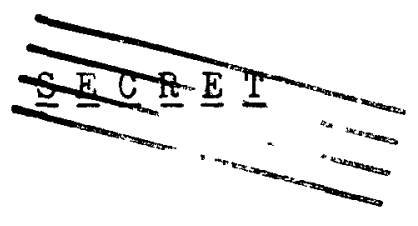

\section{CONCLUSIONS}

I) Solid solutions of $\left(\mathrm{UO}_{2}-\mathrm{ThO}_{2}\right)$ containing up to $30 \mathrm{w} / \mathrm{UO}_{2}$ show some promise at $2500^{\circ} \mathrm{F}$ from the standpoint of stability in air. Further evaluation of the system for higher temperature applications is necessary.

2) Bodies fabricated from $\mathrm{ThO}_{2}$ or $\left(\mathrm{UO}_{2}-\mathrm{ThO}_{2}\right)$ solid solution exhibit poor thermal shock resistance which severely limits their applicability as structural components in systems in which thermal cycling is to be encountered.

\section{FUTURE EXPERIMENTS}

Work is to continue in an attempt to attain pellet densities equivalent to those obtained at Argonne. These pellets will be evaluated with regard to stability in air by heating in a moving air stream at temperatures $\$ 2500^{\circ} \mathrm{F}$. Particular emphasis will be placed on compositions containing more than $50 \mathrm{w} / 0 \mathrm{ThO}_{2}$.

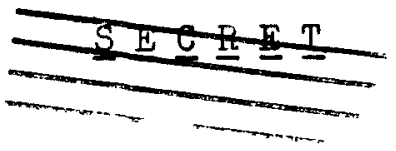

